\title{
Penggunaan Model Time Token Arends Sebagai Upaya Peningkatan Hasil Pembelajaran Menyimak Laporan Perjalanan Siswa Kelas VIIIA SMPN 1 Jelbuk Jember
}

\author{
Indana Mardiani
}

SMPN 11 Jember, Indonesia

Email: Indana8@gmail.com

\begin{tabular}{l}
\hline Tersedia Online di \\
\hline http://www.jurnal.unublitar.ac.id/ \\
index.php/briliant \\
\hline Sejarah Artikel \\
\hline Diterima pada 17 Oktober 2019 \\
Disetuji pada 8 November 2019 \\
Dipublikasikan pada 30 \\
November 2019 Hal. 424-435 \\
\hline \\
\hline Kata Kunci: \\
hasil pembelajaran menyimak, \\
model time token arends, \\
laporan perjalanan \\
DOI: \\
\hline http://dx.doi.org/10.28926/briliant \\
.v3i4.370
\end{tabular}

\begin{abstract}
Abstrak: Permasalahan yang dihadapi guru pada siswa kelas VIIIA SMPN 1 Jelbuk adalah kemampuan siswa dalam menyimak laporan perjalanan masih di bawah KKM (Kriteria Ketuntasan Minimal0 yang ditentukan sekolah. Untuk mengatasi permasalahan tersebut guru menerapkan model Time Token Arends. Tujuan penelitian ini adalah untuk mengetahui apakah dengan diterapkannya model Time Token Arends dapat meningkatkan hasil belajar siswa dalam menyimak laporan perjalanan pada siswa kelas VIIIA SMPN 1 Jelbuk Jember Semester Ganjil Tahun Pelajaran 2015/2016. Prosedur penelitian dilakukan dengan observasi awal, pada tahap ini nilai yang diperoleh siswa adalah 76 dengan ketuntasan klasikal mencapai $70 \%$ dan terdapat 11 siswa yang belum tuntas. Penelitian dilanjutkan dengan siklus I yang memperoleh rata-rata nilai 81 dan ketuntasan klasikal $81 \%$. Pada siklus II, ketuntasan klasikal mencapai $95 \%$ dan nilai rata-rata kelas 87 dan ada 2 siswa yang tidak mencapai KKM. Penelitian pada siklus II model Time Token Arends dapat meningkatkan hasil belajar siswa pada materi menyimak laporan perjalanan.
\end{abstract}

\section{PENDAHULUAN}

Bahasa Indonesia sebagai bahasa resmi digunakan secara lisan dan tulis pada berbagai forum komunikasi resmi. Komunikasi secara resmi dalam hal ini memiliki pengertian dapat memahami, mengungkapkan informasi, pikiran, perasaan, dan dapat mengembangkan ilmu pengetahuan dan teknologi, serta budaya. Berkomunikasi dalam pengertian yang utuh menurut Suryani (2013) adalah kemampuan berwacana, yakni kemampuan memahami, menghasilkan teks tertulis yang direalisasikan dalam empat keterampilan berbahasa, yaitu mendengarkan, berbicara, membaca dan menulis.

Salah satu dari empat keterampilan berbahasa tersebut, pembelajaran menyimak murapakan keterampilan reseptif yang menjadi bagian mendasar dalam berkomunikasi. Fatmawati, \& Indonesia, PBDS. (2011) menjelaskan bahwa penyimak yang aktif akan menerima, menangkap, memahami, mengingat dan mampu memberikan informasi kepada orang lain. 
Berdasarkan pendapat di atas maka pembelajaran menyimak tidak dapat dipisahkan dari tiga pembelajaran keterampilan berbehasa yang lainnya. Selain itu kegiatan menyimak tidak hanya digunakan pada pembelajaran bahasa Indonesia saja akan tetapi kegiatan pembelajaran yang lain juga tidak terlepas dari kegiatan menyimak. Dengan demikian, keterampilan menyimak ikut menentukan keberhasilan pembelajaran.

Pembelajaran menyimak yang terdapat pada kurikulum mata pelajaran bahasa Indonesia yakni tercantum pada standar kompetansi kelas VIII terdapat pada semester 1 dan 2 Kurikulum Tingkat Satuan Pendidikan, yaitu pada kompetensi dasar 1) memahami wacana lisan berbentuk laporan, 2) mengapresiasi pementasan drama, 3) memahami isi berita radio/televisi, dan 4) memahami unsur intrinsik novel remaja (asli atau terjemahan) yang dibacakan. Pada penelitian ini dipilih materi menyimak laporan perjalanan dengan alasan bahwa materi menyimak laporan perjalanan sering dialami siswa melalui cerita teman, melalui televisi, atau media lainnya. Departemen Pendidikan Nasional (2006).

Menyimak sebagai pembelajaran akan menjadi tidak efektif jika pemilihan metode dan strateginya kurang tepat. Pembelajaran menyimak akan menjadi tidak menarik jika tidak disajikan secara kreatif terutama dalam memilih dan menentukan model pembelajaran. Jika pembelajaran tidak disajikan secara kreatif dan menyenangkan tentu akan berdampak perolehan hasil belajar siswa.

Alasan pemilihan model pembelajaran Time Token Arends untuk materi menyimak laporan perjalanan pada siswa kelas VIIIA SMPN 1 Jelbuk adalah karena siswa belum memperolah hasil belajar sesuai kriteria ketuntasan minimal. Hal ini terbukti dari observasi awal yang dilakukan peneliti, kemampuan siswa dalam menyimak laporan masih di bawah kriteria ketuntasan minimal terutama untuk kompetensi dasar menganalisis laporan. Berdasarkan hasil observasi awal, ditemukan bahwa ketuntasan belajar klasikal siswa kelas VIIIA sebesar $70 \%$, sedangkan ketuntasan klasikal puntuk SMPN 1 Jelbuk adalah $85 \%$ dengan kriteria ketuntasan minimal 76.

Dengan demikian diperlukan langkah untuk mengubah strategi pembelajaran dengan memilih model Time Token Arends. Pemilihan model Time Token Arends didasari oleh pendapat Perwitasari, A., \& Abidin, Z. (2014), yang menyatakan bahwa model Time Token Arends adalah model pembelajaran yang digunakan dengan tujuan agar siswa aktif berbicara. Dengan penggunaan model Time Taken Arends pada kegiatan menyimak laporan perjalanan diharapkan siswa dapat lebih aktif memberikan umpan balik atau tanggapan baik secara lisan maupun tulis setelah kegiatan menyimak. Dengan demikian perolehan hasil belajarnya dapat meningkat.

Penerapan model Time Token Arends pada pembelajaran menyimak laporan perjalanan ini dilakukan dengan cara siswa bertukar informasi dengan temannya dalam satu kelompok. Kemudian salah satu temannya menceritakan atau menyampaikan laporan perjalanannya yang telah disiapkan. Pada kegiatan ini, undian dapat dilakukan untuk memilih urutan dalam menyampaikan cerita perjalanan atau melaporkan perjalanan.

Dengan diterapkannya metode Time Token Arends di SMPN 1 Jelbuk khususnya pada siswa kelas VIIIA, diharapkan kemampuan siswa dalam 
menyimak laporan perjalanan akan meningkat, yakni siswa dapat belajar secara tuntas, dengan mencapai ketuntasan klasikal $\geq 85 \%$.

\section{METODE}

Penelitian ini menggunakan rancangan penelitian tindakan kelas yang dilaksanakan dengan menggunakan beberapa siklus. Siklus I dilaksanakan dengan menggunakan tahap perencanaan, tindakan, observasi, dan refleksi. Tahapan ini juga digunakan untuk siklus-siklus berikutnya. Hal ini didasari bahwa penelitian tindakan kelas adalah salah satu bentuk penelitian kualitatif yang berusaha memahami dan menafsirkan makna suatu peristiwa interaksi tingkah laku manusia dalam situasi tertentu menurut perspektif peneliti sendiri. Gunawan, I. (2013), menyatakan bahwa penelitian kualitatif bertujuan untuk memahami objek yang diteliti secara mendalam. Beberapa alasan yang mendasari dipilihnya model penelitian ini, yaitu: 1) penelitian ini menjadi lebh mudah karena berhadapan dengan kenyataan, 2) pelaksanaannya secara langsung antara peneliti dengan subjek penelitian, dan 3) lebih peka dan lebih dapat menyesuaikan diri dengan kondisi lingkungan objek penelitian. (Moleong dalam Sukmadinata, S. N. 2005).

Penelitian ini melibatkan beberapa komponen yaitu siswa, guru, kepala sekolah, dan peneliti. Diadakannya penelitian ini karena atas dasar refleksi diri. Wardani, I. G. A. K. (2014), menjelaskan bahwa untuk melaksanakan penelitian tindakan kelas, guru-guru dapat melaksanakan sendiri di kelasnya dengan melibatkan siswanya melalui tindakan-tindakan yang direncanakan, dilaksanakan, dan dievaluasi, penelitian tindakan kelas dapat dilakukan tanpa mengganggu pembelajaran dan tidak akan membebani pekerjaan guru dalam melaksanakan tugas sehari-hari. Penelitian tindakan kelas dapat dilakukan secara integrasi dengan kegiatan sehari hari. Dengan penelitian tondakan kelas guru dapat meningkatkan kualitas proses dan hasil pembelajaran.

Pendapat lain mengatakan bahwa penelitian tindakan kelas merupakan suatu bentuk penelitian yang bersifat praktis karena dilakukan dengan tindakan tindakan di kelas dan bertujuan untuk memperbaiki dan meningkatkan hasil pembelajaran. (Kasihani Kasbolah, E. S., \& Sukarnyana, I. W. 1998). Teknik pelaksanaan penelitian ini menggunakan langkah-langkah siklus sebagai berikut ini.

Langkah Siklus I: (a) melaksanakan kegiatan sesuai dengan perencanaan awal; (b) membuat perencanaan berupa langkah persiapan administrasi pembelajaran berupan silabus, materi, dan rancangan evaluasi pada siklus I; (c) melaksanakan proses pembelajaran; (d) melaksanakan observasi pada proses pembelajaran berlangsung; dan (e) melakukan refleksi yaitu mengevaluasi proses pelaksanaan siklus I. Hasil refleksi siklus I digunakan untuk perencanaan siklus II. Pelaksanaan refleksi dengan cara analisis data dan hasilnya untuk revisi siklus berikutnya.

Langkah Siklus II: (a) merevisi dan penyempurnaan pelaksanaan siklus I; (b) melaksanakan proses dan pemantauan sesuai revisi siklus I. Langkah-langkah yang dilakukan pada siklus II ini adalah (1) persiapan administrasi pembelajaran berupa silabus, materi pemnelajaran, dan rancangan evaluasi pembelajaran, (2) pelaksanaan proses pembelajaran siklus II, (3) melaksanakan observasi terhadap kejadian yang muncul pada saat proses pembelajaran berlangsung ,dan (4) melakukan refleksi untuk mengevaluasi proses siklus II. Hasil refleksi siklus II ini 
digunakan untuk memberi masukan siklus III. Refleksi siklus II dilaksanakan dengan cara analisis data dan hasilnya untuk revisi siklus III.

Langkah Siklus III: (a) menyusun perencanaan berdasarkan revisi siklus I dan siklus II; (b) melaksanakan pembelajaran dan melaksanakan pemantauan. Langkah-langkah yang dilakukan pada siklus III adalah (1) menyiapkan administrasi pembelajaran yaitu silabus, materi pembelajaran, dan rancangan evaluasi, (2) melaksanakan pembelajaran siklus III, (3) melaksanakan observasi terhadap kejadian yang muncul pada saat proses pembelajaran berlangsung, dan (4) melakukan refleksi untuk mengevaluasi proses pelaksanaan siklus III. Hasil refleksi siklus III digunakan untuk menyimpulkan hasil siklus III. Hasil refleksi siklus III dilaksanakan setelah analisis data dan hasilnya merupakan kondisi akhir.

Lokasi penelitian adalah SMPN 1 Jelbuk. Objek penelitian dipilih kelas VIIIA karena kelas ini tempat peneliti mengajar. Hal ini dapat memudahkan pelaksanaan penelitian. Penelitian ini melibatkan guru mata pelajaran dan kolabulator yang sudah ditunjuk. Objek penelitian ini adalah siswa kelas VIIIA SMPN 1 Jelbuk berjumlah 37 siswa.

Teknik pengumpulan data peda penilitian ini adalah teknik tes, wawancara, dan observasi. Teknik tes digunakan untuk mengetahui tingkat pemahaman siswa dalam menyimak teks laporan perjalanan pada siswa kelas VIIIA SMPN 1 Jelbuk. Teknik wawancara digunakan untuk memperoleh data langsung dari siswa. Teknik wawancara dipilih karena berkaitan langsung dengan pembelajaran yang yang mengukur kemampuan siswa dalam memahami teks laporan perjalanan. Hal ini tidak dilakukan pada semua siswa kelas VIIIA, hanya pada siswa tertentu yang berhasil meraih nilai tinggi. Hasil wawancara digunakan sebagai subjek untuk bahan menganalisis data. Teknik observasi dilakukan untuk melihat gejala yang tampak pada saat pembelajaran berlangsung. Hal yang diobservasi berupa tingkah laku dan peran siswa dalam melaksanakan pembelajaran dengan menerapkan model yang digunakan dalam peneltian tindakan. Observasi dilakukan dengan menggunakan lembar observasi sebagai sebagai penuntun dalam mengamati objek. Hasil observasi digunakan untuk membantu mengnalisis data.

Data yang diperoleh dalam penelitian ini berupa hasil belajar siswa, hasil wawancara, dan hasil observasi. Data tersebut kemudian diolah untuk menarik simpulan yang digunakan menentukan tahapan tindakan. Data yang diperoleh dikelompokkan, dikategorikan, dan dianalisis satu persatu sehingga memunculkan nilai siswa, gambaran penilaian siswa pada proses pembelajaran.

Ada beberapa ketentuan untuk memperoleh data yang valid pada peneliti ini yaitu, (1) adanya identitas siswa (nama dan nomor absen), (2) sesuai petunjuk mengerjakan, (3) menggunakan lembar jawaban yang telah disediakan, dan (4) mengerjakan dengan sungguh-sungguh. Analisis data pada penelitian ini menggunakan teknik analisis sistematik dengan rumus (1), yaitu :

$$
M=\frac{\Sigma f X}{N}
$$

$$
\begin{array}{ll}
M & =\text { mean } \\
\Sigma f X & =\text { Jumlah Nilai Siswa } \\
N & =\text { Jumlah Siswa }
\end{array}
$$



penilaian:

Untuk mengetahui keberhasilan, Tabel 1 digunakan sebagai acuan kreteria

Tabel 1. Acuan Penilaian

\begin{tabular}{|l|l|}
\hline $\begin{array}{l}\text { Nilai } 86-100=\text { Sangat baik } \\
\text { Nilai } 76-85=\text { baik }\end{array}$ & Tuntas \\
\hline $\begin{array}{l}\text { Nilai } 50-75=\text { cukup } \\
\text { Nilai } 0-49 \quad \text { kurang }\end{array}$ & Tidak tuntas \\
\hline
\end{tabular}

Keterangan :

$\begin{array}{ll}\text { Nilai } 76-100 & =\text { tuntas } \\ \text { Nilai } 0-75 & =\text { tidak tuntas }\end{array}$

Ketuntasan Klasikal adalah $85 \%$ artinya jika $85 \%$ dari jumlah siswa memperoleh nilai di atas 76 maka kelas tersebut dikatakan tuntas. Kegiatan pelaksanaan tindakan yang akan dilaksanakan adalah untuk menerapkan rencana pembelajaran yang telah ditetapkan dan disertai observasi terhadap aktivitas siswa. Siswa juga akan diberi lembaran pendapat dan tanggapan terhadap model pembelajaran yang diterapkan pada materi laporan teks perjalanan.

Penelitian ini direncanakan dua siklus. Setiap siklus mempunyai memiliki tahapan yaitu : perencanaan, pelaksanaan, observasi, dan refleksi. Keempat tahap tersebut dapat digambarkan dengan Gambar 1.

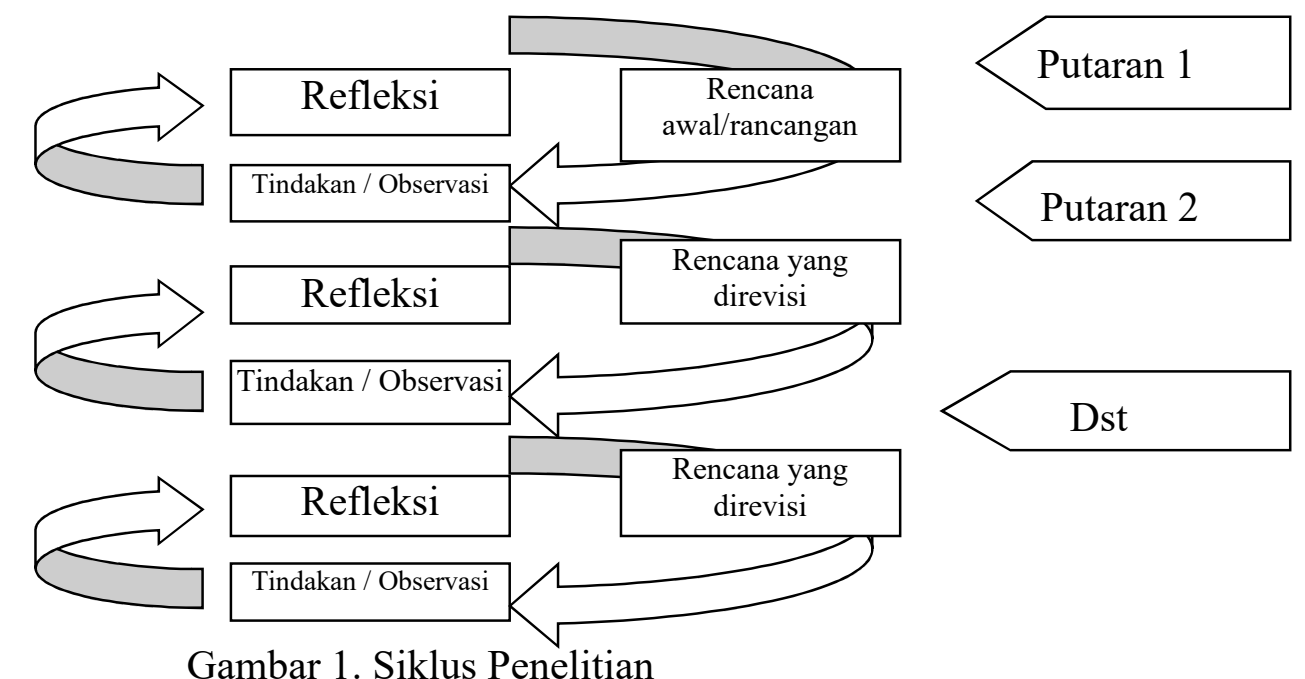

Adapun siklus dalam penelitian ini meliputi: a. Perencanaan Tindakan: peneliti menyiapkan rancangan pembelajaran yang memuat model Time Token Arends pada materi menyimak laporan perjalanan. Peneliti juga menyiapkan lembar penilaian keaktifan siswa serta lembar pendapat dan tanggapan dari siswa. b. Pelaksanaan Tindakan: selama proses pembelajaran berlangsung, guru mengajar sesuai dengan rencana pembelajaran yang telah dibuat dan diterapkan dengan model Time Token Arends . Langkah-langkah pelaksanaan model tersebut dapat dijelaskan sebagai berikut :1) siswa secara individu menyimak laporan perjalanan yang diperdengarkan oleh guru; 2) siswa melaksanakan diskusi kelompok, setiap kelompok terdiri dari 4-6 orang; 3) setiap siswa diberi kupon 
undian; 4) siswa menyampaikan hasil simakannya kepada anggota kelompoknya sesuai nomor undian yang didapatkan; 5) kupon undian diserahkan kepada guru agar siswa tersebut tidak mendapat giliran lagi. c. Observasi: pelaksanaan observasi dilakukan untuk merekam semua aktivitas dan kemampuan yang ditunjukkan siswa selama kegiatan pembelajaran di kelas yang meliputi keaktifan siswa, kemampuan bertanya, kemampuan menjawab pertanyaan, dan kemampuan menyampaikan pendapat. $d$. Refleksi: data yang diperoleh pada tahap observasi selanjutnya dianalisis. Hal ini untuk melihat kegiatan apakah kegiatan pembelajaran sudah sesuai dengan metode yang digunakan. Selanjutnya hasilnya dibahas/didiskusikan antarsiswa, peneliti, dan guru yang lain. Hasil penilaian keaktifan siswa, hasil pendapat, dan tanggapan siswa akan dijadikan bahan pertimbangan.

Kegiatan diskusi ini bertujuan untuk mengetahui hasil pelaksanaan tindakan dan untuk mencari jalan keluar terhadap masalah yang ada sehingga dapat dibuat rencana tindakan pada siklus II.

\section{HASIL}

Pada tahap observasi awal, guru melakukan analisis ulangan harian. Pada hasil ulangan harian terakhir pembelajaran masih menggunakan model konvensional. Hal ini dijadikan titik tolak kondisi awal siswa sebelum dilakukan penelitian atau kondisi sebelum siswa kelas VIIIA mendapatkan perlakuan penggunaan model Time Token Arends.

Berdasarkan data pada observasi awal yang dilakukan peneliti yang didukung dengan hasil wawancara dengan beberapa siswa di kelas VIIIA ditemukan bahwa masih terdapat banyak siswa yang memiliki nilai di bawah kriteria ketuntasan minimal yang ditentukan sekolah. Kriteria ketuntasan minimal untuk mata pelajaran bahasa Indonesia di SMPN 1 Jelbuk adalah 76, dengan demikian dapat dikatakan bahwa ketuntasan belajar di kelas VIIIA masih jauh dengan kriteria ketuntasan minimal klasikal yaitu $85 \%$.

Data di atas menunjukkan bahwa ada 13 siswa yang nilainya masih di bawah kriteria ketuntasan minimal dan ada 26 Siswa yang memiliki nilai sama atau di atas kriteria ketuntasan minimlal. Selain itu ditemukan bahwa semangat belajar siswa dalam mengikuti pelajaran bahasa Indonesia sangat kurang, hal ini didasari dari wawancara peneliti dengan beberapa siswa di kelas VIIIA pada saat sebelum perlakuan dengan menerapkan model Time Token Arends. Hasil observasi menunjukkan bahwa siswa banyak yang kurang senang terhadap pembelajaran bahasa Indonesia dengan beberapa alas an, seperti kurang menarik, siswa merasa jenuh dengan pembelajaran klasikal (konvensional), dan beberapa jawaban siswa saat wawancara yang menunjukkan kurang berminatnya siswa terhadap mata pelajaran bahasa Indonesia. Hal ini sangat berkaitan langsung dengan rendahnya hasil belajar diperoleh siswa, terutama siswa di kelas VIIIA.

Berdasarkan hasil temuan peneliti pada observasi awal, maka peneliti akan melakukan perlakuan dalam pembelajaran bahasa Indonesia materi menyimak laporan perjalanan dengan menggunakan model Time Token Arends. Adapun tahapan siklus yang akan dilakukan sebagai berikut ini.

Pada Siklus I tahapan yang akan dilakukan adalah 1) perencanaan. Pada tahap ini sebelum pelaksanaan tindakan, peneliti sekaligus pelaksana tindakan berkolaborasi dengan wali kelas untuk merencanakan hal-hal yang perlu 
dipersiapkan, di antaranya adalah RPP, lembar Penilian, Media Pembelajaran, dan kupon yang akan digunakan dalam pembelajaran dengan model Time token Arends. 2) tindakan. Pada tahap ini, kegiatan yang dilakukan adalah sebagai: a.Kegiatan Awal/Apersepsi : 1) guru mengucapkan salam dan mempersilakan siswa berdoa sesuai agama dan kepercayaan masing-masing; 2) siswa mendengarkan penjelasan guru tentang tujuan pembelajaran dan kompetensi yang akan dicapai dalam pembelajaran; 3) siswa mendengarkan penjelasan guru tentang materi yang akan dipelajari; 4) guru memberi contoh tentang laporan perjalanan. b. Kegiatan Inti/ Eksplorasi : 1) guru bertanya kepada beberapa siswa apakah pernah melakukan perjalanan, seperti rekreasi ke tempat wisata, berkunjung ke rumah teman atau saudara, berkunjung ke tempat-tempat hiburan, dll.; 2) siswa menjelaskan secara singkat tentang perjalanan yang pernah dilakukan; 3) guru memberikan beberapa pertanyaan mengenai perjalan yang dilakukan siswa, berkaitan dengan waktu, kegiatan yang dilakukan dll; 4) guru memfasilitasi terjadinya interaksi antarsiswa serta antara siswa dengan guru, lingkungan, dan sumber belajar lainnya, dengan cara mempersilakan siswa memberikan pertanyaan singkat mengenai perjalanan yang dilakukan temannya (kegiatan menggali rasa ingin tahu siswa); 5) guru memfasilitasi siswa untuk dapat menganalisis laporan. 2. Elaborasi : dengan melakukan 1) guru memberikan penguatan tentang laporan perjalanan; 2) Guru memilih satu siswa yang memiliki cerita perjalanan yang menarik untuk menceritakan secara lengkap mengenai perjalanan yang dilakukannya; 3) guru menfasilitasi siswa untuk membentuk kelompok yang beranggotakan 5-6 siswa; 4) guru membagikan kupon kepada setiap kelompk sesuai dengan jumlah anggota kelompoknya; 5) Kupon berfungsi sebagai tiket untuk memberikan tanggapan, saran, kritik dll. (1 kupon $=1$ kesempatan); 6) guru menfasilitasi siswa untuk mendengarkan laporan perjalanan yang disampaikan salah satu teman yang telah ditunjuk oleh guru; 7) guru menfasilitasi siswa untuk menganalisa laporan perjalanan secara kelompok; 8) setelah melakukan diskusi kelompok, guru menunjuk kelompok secara bergiliran untuk menyampaikan hasil analisis dari kelompok tersebut; 9) setiap anggota kelompok berhak menyampaikan saran, kritik, dan tanggapan berkaitan dengan hasil analisis kelompok lain, dengan catatan setelah siswa tersebut memberikan komentar, saran, kritik, siswa tersebut harus menyerahkan kembali kupon kepada guru (kupon sebagai tiket untuk memberikan tanggapan). 3. Konfirmasi : dilakukan dengan cara 1) guru memberikan tanggapan terhadap hasil analisis teks laporan perjalanan yang dibuat oleh setiap kelompok; 2) guru memberikan konfirmasi terhadap hasil eksplorasi dan elaborasi siswa; 3) guru memfasilitasi siswa untuk melakukan refleksi dalam proses pembelajaran; 4) guru memfasilitasi siswa untuk memperoleh pengalaman yang bermakna dalam mencapai kompetensi dasar (Hal ini dapat digunakan oleh narasumber dan fasilitator dalam menjawab pertanyaan peserta didik yang menghadapi kesulitan, dengan menggunakan bahasa yang baik dan benar, membantu menyelesaikan masalah, memberi acuan agar peserta didik dapat melakukan pengecekan hasil eksplorasi, memberi informasi untuk bereksplorasi lebih jauh, dan memberikan motivasi kepada peserta didik yang kurang atau belum berpartisipasi aktif); 5) guru bertanya jawab tentang hal-hal yang belum diktahui siswa; 6) guru bersama siswa bertanya jawab meluruskan kesalahan pemahaman, memberikan penguatan, dan penyimpulan. c. Kegiatan Akhir:1) guru bersama-sama siswa dan/atau sendiri 
membuat rangkuman/simpulan pembelajaran; 2) guru melakukan penilaian dan/atau refleksi terhadap kegiatan yang sudah dilaksanakan; 3) guru memberikan umpan balik terhadap proses dan hasil pembelajaran; 4) guru merencanakan kegiatan tindak lanjut dalam bentuk remedi, pengayaan, layanan konseling dan/atau memberikan tugas baik tugas individual maupun kelompok sesuai dengan hasil belajar siswa. 2. Observasi: pada tahap ini proses pembelajaran tergambar untuk mengetahui hasil penilaian. Pada pembelajaran dengan menggunakan moderl Time Token Arends, peneliti melakukan penilaian yang meliputi penilaian menulis laporan perjalan, menulis beberapa kalimat, dan menulis beberapa hal-hal menarik dari laporan perjalanan, kemudian hasil skor dari beberapa kegiatan tersebut dikumpulkan dan diolah kemudian dikonversi ke dalam nilai dengan skala 10-100.

Berdasarkan hasil penilaian dapat diketahui bahwa skor rata-rata yang diperoleh adalah 80 . Hal itu berarti bahwa nilai rata-rata kelas pada pembelajaran menyimak laporan perjalanan dapat dikonfirmasikan ke dalam kriteria yang telah ditentukan. Kemampuan tersebut tergolong baik atau tuntas secara individu, akan tetapi ketuntasan klasikal pada siklus I adalah sebesar $81 \%$ artinya secara klasikal siswa kelas VIIIA masih belum tuntas karena $81 \% \leq 85 \%$. Perolehan skor tabel siklus I, dapat dikatakan bahwa hasilnya dinilai baik, karena dari 37 siswa, yang mendapat nilai diatas 76 adalah sebanyak 30 siswa, dan yang mendapat nilai di bawah 76 (belum tuntas) sebanyak 7 siswa, sehingga perlu adanya perbaikan lagi pada siklus berikutnya. Dari deskripsi data tersebut dapat dianalisis sebagai berikut : (a) hasil pembelajaran dengan menggunakan model Time Token Arends masih dinilai cukup, karena pengembangan masih sederhana; (b) sebagian kecil masih ada siswa yang mengalami kesulitan dalam menggunakan kesempatan mengemukakan pendapat dengan menggunakan kupon yang diberikan. 3 . Refleksi: berdasarkan deskripsi dan analisis data dapat disimpulkan sebagai berikut : (a) masih ada kelompok yang dominan dalam kegiatan pembelajaran, hal ini disebabkan dalam kelompok tersebut merupakan kelompok yang beranggotakan siswa yang pandai; (b) menyimak laporan perjalanan merupakan pengalaman yang disenangi siswa karena siswa bisa mengomentari dengan menggunakan tiket kupon; (c) sebagian besar kelompok mampu menuliskan laporan hasil menyimak laporan perjalanan; (d) masih ada anggota beberapa kelompok yang bingung dalam proses pembelajaran dengan model Time Token Arends, (e) waktu yang digunakan dalam pembelajaran masih belum optimal karena guru masih terlalu banyak memberikan petunjuk, (f) sebagian besar siswa berkesempatan berpendapat, walaupun pendapat yang diutarakan masih belum mengena atau sedikit melenceng dari materi yang ada.

Berdasarkan refleksi di atas, saran yang diberikan untuk siklus II sebagai berikut: (a) melakukan pembagian kelompok berdasarkan kemampuan individu, hal ini dilakukan agar persebaran kemampuan siswa merata pada setiap kelompok, hal ini untuk menghindari dominasi kelompok tertentu; (b) guru menjelaskan kepada siswa yang masih belum mengerti tentang pembelajaran model Time Token Arends, tentang aturan dalam pembelajaranya; (c) guru lebih mengoptimalkan waktu pembelajaran agar semua siswa mempunyai kesempatan untuk mengemukakan pendapat dan berperan aktif dalam pembelajaran; (d) guru menekankan kepada siswa agar siswa fokus pada materi yaitu tentang menyimak teks laporan perjalanan. 
Pada Siklus II tahapan yanga dilakukan adalah: 1. Perencanaan: Perencanaan pada siklus II sama dengan siklus I. Perencanaan berisi kesiapan materi teks laporan perjalanan, pembuatan silabus, RPP, analisis, kondisi siswa, penyiapan materi, dan penyiapan media yang akan digunakan. Pembelajaran direncanakan sesuai dengan pembelajaran menyimak dengan model Time Token Arends. Guru merencanakan kegiatan siswa di kelas berupa pemberian tugas dan waktu yang lebih banyak dari siklus I. Siswa direncanakan dapat mengembangkan keterampilannya dalam menyimak dan menulis laporan. Pada siklus ini peneliti melakukan beberapa perbaikan berdasarkan hasil temuan dan refleksi pada siklus I dengan tujuan pada siklus II ketuntasan belajar siswa baik individu maupun klasikal dapat tuntas sesuai dengan kriteria yang telah ditentukan. 2. Tindakan: dalam Siklus II ini pembelajaran menggunakan model Time Token Arends dilakukan di kelas VIIIA. Adapun kegiatan awal pembelajaran semua seperti biasa, kegiatannya adalah : a. Kegiatan Awal/Apersepsi : 1) siswa mendengarkan laporan perjalanan dari media yang ditayangkan oleh guru; 2) membuat contoh sebuah paragraf yang menerangkan tempat, kegiatan, dan waktu. b. Kegiatan Inti/ Eksplorasi: dilakukan dengan cara 1) guru memberikan gambaran mguru melibatkan siswa untuk aktif dan menanyakan beberapa hal berkaitan dengan kegiatan pembelajaran pada materi sebelumnya; 3) guru menggunakan beragam pendekatan pembelajaran, media pembelajaran, dan sumber belajar lain; 4) guru memfasilitasi terjadinya interaksi antarsiswa serta antarasiswa dengan guru, lingkungan, dan sumber belajar lainnya; 5) melibatkan siswa secara aktif dalam setiap kegiatan pembelajaran; dan 6) guru memfasilitasi siswa menganalisis laporan.

Elaborasi: pada kegiatan ini 1) guru menfasilitasi siswa untuk membentuk kelompok dengan anggota setiap kelompok terdiri dari 5-6 Siswa.; 2) guru membagikan kupon tiket untuk mengungkapkan pendapat, saran, dan kritik kepada setiap anggota kelompok sesuai anggota kelompoknya; 3) guru memfasilitasi siswa mendengarkan dan menyimak sebuah laporan perjalanan dari nara sumber ( salah satu guru yang telah melakukan sebuah perjalanan wisata ke Pulau Bawean); 4) guru memfasilitasi siswa mengenali laporan perjalanan : guru menfasilitasi siswa untuk berdiskusi dengan teman kelompoknya mengenai laporan perjalanan yang telah disimak; 6) setelah melakukan diskusi kelompok guru menunjuk kelompok secara bergiliran untuk menyampaikan hasil analisisnya; 7) setiap anggota kelompok berhak menyampaikan saran, kritik, dan tanggapan berkaitan dengan hasil analisis kelompok lain, dengan catatan setelah siswa tersebut memberikan komentar, saran, kritik, siswa tersebut harus menyerahkan kembali kupon kepada guru (kupon sebagai tiket untuk memberikan tanggapan); 8) guru memfasilitasi siswa membuat laporan eksplorasi yang dilakukan baik lisan maupun tertulis, secara individual maupun kelompok.

Konfirmasi: kegitan ini dilakukan dengan cara 1) guru memberikan umpan balik positif dan penguatan dalam bentuk lisan, tulisan, isyarat, maupun hadiah terhadap keberhasilan siswa; 2) guru mmberikan konfirmasi terhadap hasil eksplorasi dan elaborasi siswa melalui berbagai sumber; 3) guru memfasilitasi siswa melakukan refleksi untuk memperoleh pengalaman belajar yang telah dilakukan; 4) guru memfasilitasi siswa untuk memperoleh pengalaman yang bermakna dalam mencapai kompetensi dasar: berfungsi sebagai narasumber dan fasilitator dalam menjawab pertanyaan peserta didik yang menghadapi kesulitan, 
dengan menggunakan bahasa yang baik dan benar, membantu menyelesaikan masalah, memberi acuan agar peserta didik dapat melakukan pengecekan hasil eksplorasi, memberi informasi untuk bereksplorasi lebih jauh, memberikan motivasi kepada peserta didik yang kurang atau belum berpartisipasi aktif.; 5) guru bertanya jawab tentang hal-hal yang belum diktahui siswa; dan 6) guru bersama siswa bertanya jawab meluruskan kesalahan pemahaman, memberikan penguatan dan penyimpulan.

Kegiatan pada tahap ini adalah 1) guru bersama-sama siswa dan/atau sendiri membuat rangkuman/simpulan pembelajaran; 2) guru melakukan penilaian dan/atau refleksi terhadap kegiatan yang sudah dilaksanakan; 3) guru memberikan umpan balik terhadap proses dan hasil pembelajaran; 4) guru merencanakan kegiatan tindak lanjut dalam bentuk pembelajaran remedi, pengayaan, layanan konseling dan/atau memberikan tugas baik tugas individual maupun kelompok sesuai dengan hasil belajar siswa; 5) siswa mencatat hal-hal penting dalam teks laporan perjalanan. Observasi: kegiatan ini dilaksanakan pada saat proses pembelajaran dan hasil kegiatan observasi ini adalah : (a) kegiatan menyimak laporan perjalanan melalui media tayang merupakan hal yang sangat disukai oleh siswa karena siswa bisa menyerap informasi dari media yang ditayangkan; (b) hampir semua kelompok mampu bekerja sama dengan baik dalam kegiatan menganalisis teks laporan perjalanan yang ditampilkan oleh guru melalui media tayang.

Berdasarkan hasil Siklus II, diperoleh data rata-rata nilai klasikal adalah 88. Berdasarkan kriteria yang telah ditentukan, kemampuan perolehan nilai tersebut tergolong baik dan tuntas, karena dari 37 siswa hanya 2 orang yang belum tuntas dan sisanya 35 siswa tuntas dengan nilai yang baik. Jika dilihat dari persentase ketuntasan klasikal, besaran ketuntasan klasikal pada siklus II adalah 95\%. Hal ini lebih besar dari kriteria ketuntasan klasikal yaitu $85 \%$, sehingga pada siklus ini penelitian dihentikan karena tujuan penelitian sudah tercapai.

Dari uraian di atas, dapat dianalisis sebagai berikut: (a) proses pembelajaran dikatakan baik, karena kegiatan pembelajaran mencerminkan kegiatan pembelajaran aktif; (b) siswa senang belajar karena merasa mudah dalam memahami materi pembelajaran; (c) dalam menyusun laporan hasil siswa mampu menghasilkan laporan yang baik sesuai kriteria penilaian. Refleksi: berdasarkan kegiatan observasi di atas dapat direfleksikan bahwa penelitian dengan model Time Token Arends mampu meningkatkan kualitas pembelajaran khususnya di kelas VIIIA SMPN 1 Jelbuk, hal ini karena pada kelas tersebut sudah mencapai ketuntasan klasikal sebesar $95 \%$ dengan rata-rata nilai 88, ada 2 siswa yang belum tuntas, akan tetapi hal itu dianggap wajar dikarenakan beberapa faktor di luar penelitian tindakan ini. Untuk selanjutnya diharapkan akan dilakukan penelitian sejenis untuk menganalisis dan membahas hal tersebut. Secara umum penelitian ini sesuai dengan tujuan dan harapan yang diajukan peneliti dan sesuai hipotesis penelitian, sehingga penelitian ini dihentikan pada siklus II.

\section{PEMBAHASAN}

Tujuan penggunaan model Time Token Arends adalah untuk melatih siswa agar lebih tanggap menerima pesan dari orang lain dan mampu menyampaikan pesan tersebut kepada teman sekelompoknya. Kegiatan yang dilakukan adalah berbagai informasi dengan cara menggunakan kupon pengundian. Siswa yang 
namanya disebut menyampaikan kupon pengundiannya dan mendapatkan giliran untuk menyampaikan laporan dari hasil proses menyimaknya. Siswa lain dalam kelompoknya menyimak laporan temannya untuk kemudian memberikan pertanyaan atau tanggapan terhadap laporan temannya. Model Time Token Arends secara umum mempunyai kelebihan yaitu untuk melatih kesiapan siswa dalam menerima, memahami, dan menyampaikan pesan kepada orang lain sesuai dengan kuponnya. Siswa dituntut mempunyai tanggung jawab baik untuk dirinya sendiri maupun orang lain. Berdasarkan hasil tersebut, menunjukkan bahwa strategi Time Token Arends telah teruji efektif jika digunakan dalam pembelajaran menyimak laporan perjalanan.

Penelitian yang dilakukan pada siswa kelas VIIIA SMPN 1 Jelbuk menunjukkan hasil adanya peningkatan kualitas pembelajaran mulai dari observasi awal yang menunjukkan bahwa nilai rata-rata siswa sebesar 76 dengan ketuntasan klasikal hanya mencapai $70 \%$ dan terdapat 11 siswa yang belum tuntas. Pada siklus I rata-rata nilai meningkat menjadi 80 dan ketuntasan klasikal mencapai $81 \%$, sedangkan pada siklus II setelah peneliti melakukan evaluasi, refleksi, dan revisi berdasarkan data yang diperoleh pada siklus I terdapat peningkatan yang signifikan yaitu siklus II ketuntasan klasikal mencapai 95\% dan naiknya nilai rata-rata kelas menjadi 88 dan ada 2 siswa yang tidak tuntas. Pada siklus II tujuan dan harapan peneliti tercapai sehingga penelitian dengan menggunakan model Time Token Arends dihentikan.

Progres pada setiap tahapan penelitian tindakan sebagai berikut ini. Pada prasiklus nilai rata-rata kelas 76 dengan ketuntasan 70\%, pada Siklus I nilai ratarata kelas 81 dengan ketuntasan $80 \%$, dan pada Siklus II nilai rata-rata kelas menjadi 88 dengan persentase ketuntasan 95\%. Peningkatan nilai rata-rata dan ketuntasan tersebut menunjukkan bahwa model Time Token Arends dapat membantu siswa dalam memahami isi laporan perjalanan yang diperdengarkan.

Penggunaan model Time Token Arends merupakan salah satu alternatif bagi guru dalam pembelajaran menyimak laporan perjalanan. Dengan digunakannya model pembelajaran ini siswa menjadi senang belajar dan dapat memahami materi pembelajaran dengan mudah. Hal tersebut menunjukkan bahwa penggunaan model Time Token Arends dapat membantu tercapainya hasil belajar yang diinginkan. Model Time Token Arends menciptakan suasa belajar yang mendukung proses pembelajaran yang menyenangkan. Model ini mampu menciptakan pembelajaran yang aktif (siswa melakukan diskusi dengan aktif), kreatif (siswa mampu mengeluarkan ide dan tanggapan dari hasil kegitan menyimak), kolaboratif (siswa saling melengkapi jawaban antaranggota kelompok), kompetitif (adanya kompetisi yang sehat untuk meraih hasil maksimal), dan kooperatif (adanya kerja sama antaranggota kelompok). Hal ini dapat terlihat dari kegiatan pembelajaran dan hasil penilaian tes kemampuan menyimak.

\section{KESIMPULAN}

Hasil penelitian ini dapat disimpulkan bahwa dengan digunakannya model Time Token Arends dapat meningkatkan hasil belajar menyimak laporan perjalanan pada siswa kelas VIIIA SMPN 1 Jelbuk Jember. 


\section{SARAN}

Berdasarkan hasil penelitian tindakan ini, disampaikan beberapa saran sebagai berikut: (1) Kepada guru, agar menggunakan model pembelajaran yang bervariasi yang dapat menjadikan siswa aktif dalam kegiatan pembelajaran khususnya menyimak; (2) Kepada siswa, disarankan untuk banyak berlatih dalam kegiatan menyimak agar memiliki daya simak yang baik; (3) Kepada peneliti, perlu diadakan penelitian lebih lanjut untuk mengetahui pemanfaatan model Time Token Arends dalam materi pembelajaran menyimak yang lain.

\section{DAFTAR PUSTAKA}

Departemen Pendidikan Nasional. 2006. Kurikulum 2006. Jakarta.

Fatmawati, N. Y., \& INDONESIA, P. B. D. S. (2011). Keefektifan Strategi Time Token Arends terhadap Kemampuan Menyimak Laporan Perjalanan pada Siswa Kelas VIII SMP N 1 Wonosari Gunungkidul.

Gunawan, I. (2013). Metode penelitian kualitatif. Jakarta: Bumi Aksara.

Kasihani Kasbolah, E. S., \& Sukarnyana, I. W. (1998). Penelitian Tindakan Kelas (PTK). Dikti, Proyek Pendidikan Guru Sekolah Dasar, Jakarta.Keraf, Gorys. 1990. Komposisi, Ende: Nusa Indah

Perwitasari, A., \& Abidin, Z. (2014). Peningkatan Kualitas Pembelajaran Pkn Melalui Model Time Token Arends Dengan Media Audio Visual. Joyful Learning Journal, 3(1).

Sukmadinata, S. N. (2005). Metode Penelitia. Bandung: PT Remaja Rosdakarya.

Suryani, Eli. 2013. Peningkatan Kemampuan Menyimak Cerita Anak dengan Metode Simak Ulang Ucap pada Mata Pelajaran Bahasa Indonesia.Universitas Islam Negeri Sultan Syarif Kasim Riau2013.repository.uin-suska.ac.id

Wardani, I. G. A. K. (2014). Penelitian tindakan kelas. Jakarta: Universitas Terbuka 